\title{
Chiron approaches to polyhydroxylated piperidines: promising glycosidase inhibitors
}

\author{
Dilip D. Dhavale*, Vijaya N. Desai, Nabendu N. Saha, and Jayant N. Tilekar \\ Department of Chemistry, Garware Research Centre, University of Pune, Pune - 411 007, India \\ E-mail: ddd@chem.unipune.ernet.in
}

\author{
Dedicated to Prof. S. V. Kesser on the occasion of his $70^{\text {th }}$ birthday \\ (received 03 May 02; accepted 06 Jul 02; published on the web 14 Jul 02)
}

\begin{abstract}
New chiron approaches towards the syntheses of polyhydroxylated piperidine analogues are described. The methodologies involve 1,3-addition of methyl magnesium bromide and silyl ketene acetal to D-glucose derived nitrone, intramolecular Michael addition to D-glucose derived $\alpha, \beta$-unsaturated ester and double reductive amination of 5-keto aldose as key steps.
\end{abstract}

Keywords: Alkaloids, piperidines, nitrone, reductive amination, conjugate addition, enzyme inhibitors

\section{Introduction}

In the last two decades, glycosidase inhibitors such as polyhydroxylated piperidines, commonly known as azasugars, have been attractive target molecules for synthetic chemists as well as biochemists not only because they serve as a useful tool for studying the biological function of oligosaccharides $^{1}$ but also because they have great potential as drugs in the treatment of a variety of carbohydrate mediated diseases. ${ }^{2}$ Amongst these azasugars, nojirimycin (1) and 1deoxynojirimycin (2) are the first naturally occurring alkaloids with promising glycosidase inhibitory activity. ${ }^{3}$ In order to examine the structure-activity relationship, a number of synthetic analogues of $\mathbf{1}$ and $\mathbf{2}$ have been synthesized and evaluated for glycosidase inhibition in the treatment of various diseases such as diabetes, cancer, AIDS and viral infections. ${ }^{4}$ This study established the correlation between the $\alpha / \beta$-glycosidase inhibitory activity with the positions,and the configurations of $-\mathrm{OH}$ groups as well as various substituents (in lieu of $-\mathrm{OH}$ groups). ${ }^{5}$ As a part of our continuing interest in sugar chemistry, we have developed new synthetic routes towards known and unknown analogues of polyhydroxylated piperidine alkaloids. An account of our studies is discussed herein. 


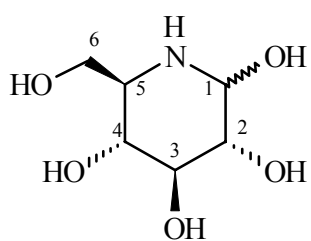

1

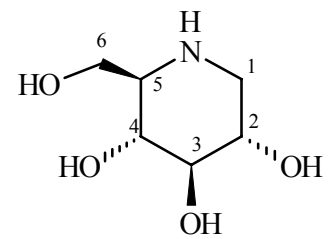

2

Figure 1

\section{Review}

\section{Synthesis of 6-deoxynojirimycin (3)}

Our first approach involves synthesis of 6-deoxynojirimycin 3. In this method, we have visualized the formation of piperidine ring skeleton in 3 by joining $\mathrm{C}-\mathrm{N}$ bond between $\mathrm{C}-5$ amino- and C-1 aldehyde functionality of D-glucose derivative. The C-5 amino sugar was therefore an apparent key intermediate that could be obtained from 1,3-addition of methylmagnesium bromide to D-glucose derived nitrone ${ }^{6}$. Thus, the reaction of 1,2-Oisopropylidene-3-O-benzyl- $\alpha$-D-xylo-pentodialdose (4) with $N$-benzylhydroxylamine hydrochloride, in the presence of sodium acetate in methanol-water, afforded a nitrone 5 (Scheme 1). The 1,3-addition of methylmagnesium bromide to 5 gave a diastereomeric mixture of D-gluco- and L-ido-configurated $N$-hydroxylamines 6a and $\mathbf{6 b}$ in the ratio 61:39 respectively, which was separated by flash chromatography. The trimethylsilyl triflate catalyzed 1,3-addition of methylmagnesium bromide, however, gave a good diastereoselectivity in favor of D-glucoisomer (D-gluco:L-ido $=88: 12$ ). The $\mathrm{N}-\mathrm{O}$ bond reductive cleavage of 6 a with zinc-acetic acid followed by hydrogenolysis of benzyl groups afforded 1,2-O-isopropylidene-5,6-dideoxy-5amino- $\alpha$-D-gluco-furanose (7). Purging sulfur dioxide gas through a solution of 7 in methanolwater at $0{ }^{\circ} \mathrm{C}$ for $48 \mathrm{~h}$ gave a bisulphite adduct of 6-deoxynojirimycin 8 as a white solid. Compound 8 was passed through a basic resin and eluted with distilled water which afforded 6deoxynojirimycin $\mathbf{3}$ as a pale yellow solid. The spectral and analytical data was in accordance with structure 3. Shortly after our report Defoin et al reported the synthesis of 6deoxynojirimycin ${ }^{7}$. 
D Glucose
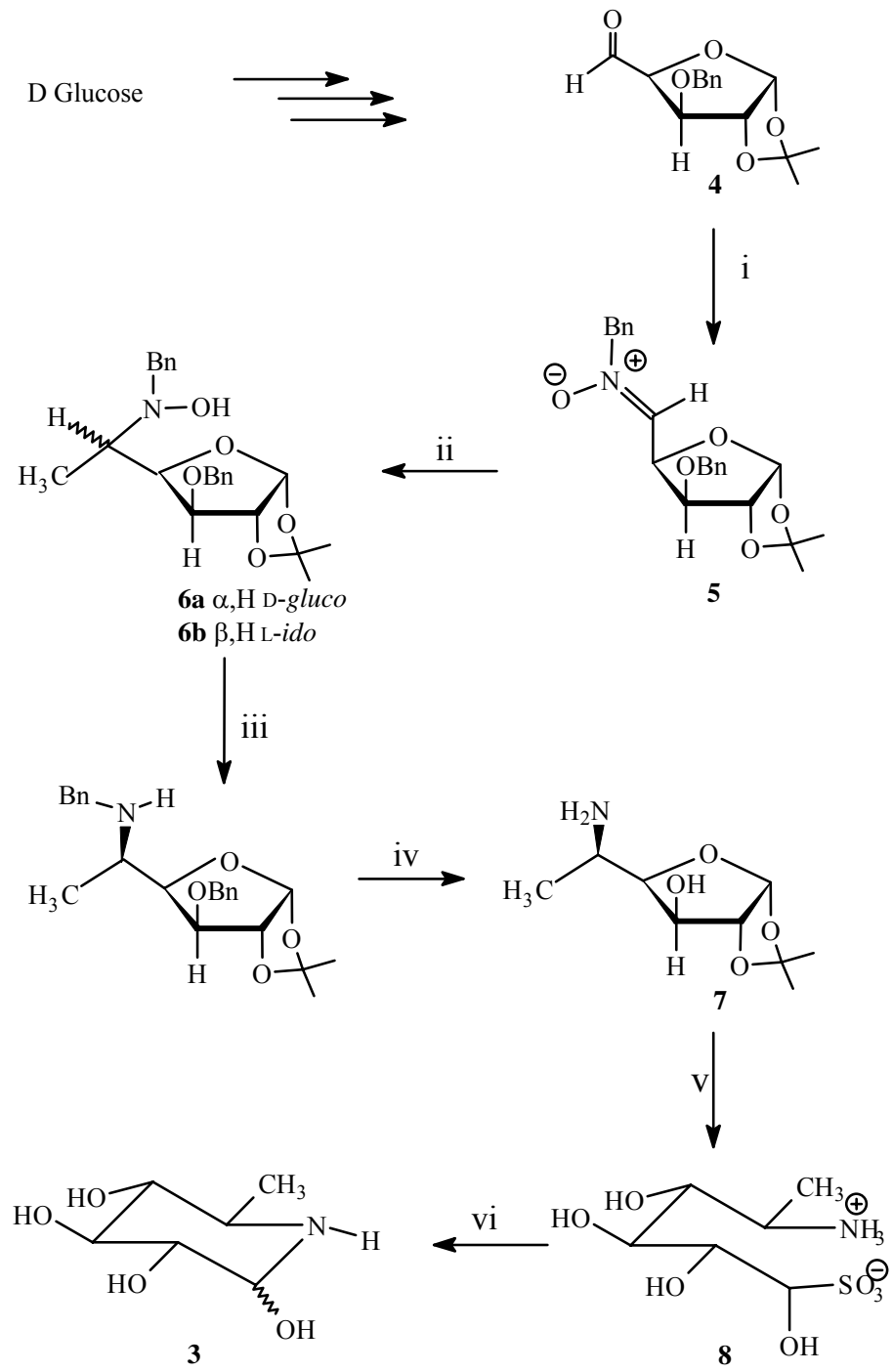

Scheme 1. Reagents and conditions: (i) $\mathrm{NH}(\mathrm{OH}) \mathrm{Bn}-\mathrm{HCl}, \mathrm{CH}_{3} \mathrm{COONa}, \mathrm{MeOH}-\mathrm{H}_{2} \mathrm{O}$, rt, 2h; (ii) $\mathrm{MeMgCl}$, THF $-30^{\circ} \mathrm{C}$, 3h; (iii) $\mathrm{Zn}-\mathrm{AcOH}, 70^{\circ} \mathrm{C}, 2 \mathrm{~h}$; (iv) $\mathrm{HCOONH}_{4}, 10 \% \mathrm{Pd} / \mathrm{C}, \mathrm{MeOH} 12 \mathrm{~h}$;(v) $\mathrm{SO}_{2} \mathrm{Gas}, \mathrm{MeOH}, 35^{\circ} \mathrm{C}$.

The observed facial diastereoselectivity in favor of product 6a, arising from nucleophilic attack to the $R e$ face of the nitrone, may be rationalized by assuming the preferred conformation A for nitrone 5 (Figure 2). According to the Felkin model the large substituent is perpendicular to the $\mathrm{C}=\mathrm{N}$ bond. We believe that $\mathrm{C}-\mathrm{O}$ bond will adopt this position; in fact it is known that nucleophilic attack seeks the LUMO of nitrone which may be stabilized through mixing of the $\pi^{*}{ }_{\mathrm{C}=\mathrm{N}}$ orbital with the lowest energy $\sigma^{*}$ orbital of a substituent that is generally associated with the most electronegative group. On these grounds, A offers the favorable trajectory to the incoming nucleophile and this is magnified after $O$-silylation by trimethylsilyl triflate leading to the formation of the D-gluco isomer as the major product. 


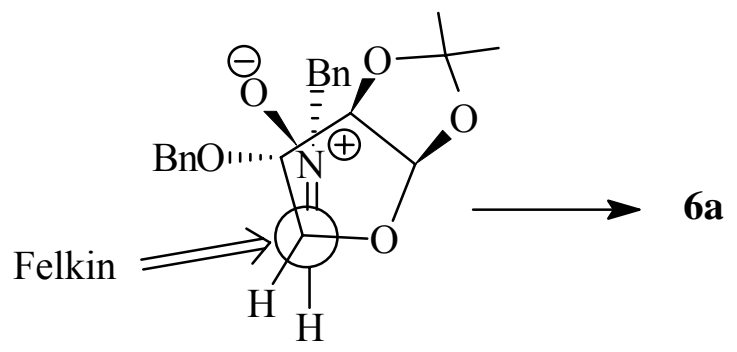

Figure 2

\section{Synthesis of 1,6-dideoxy-nojirimycin (9)}

In this approach, we have applied a double reductive amination of a C5-keto aldose as a key step in the formation of a target compound. Thus, the reaction of 1,2-O-isopropylidene-3-O-benzyl$\alpha$-D-xylo-pentodialdose (4) with ethyl diazoacetate in the presence of catalytic amounts of boron trifluoride ethyl etherate afforded sugar $\beta$-keto ester $\mathbf{1 0}$ in good yield (Scheme 2) ${ }^{8}$. Decarboxylation of $\mathbf{1 0}$ using sodium chloride in wet dimethylsulfoxide afforded C5-keto sugar 11. Hydrolysis of 1,2-O-isopropylidene functionality in compound $\mathbf{1 1}$ gave 6-deoxy-3-O-benzyl$\alpha$-D-xylo-hexofuran-5-ulose (12). The critical double reductive amination reaction with benzhydrylamine, sodium cyanoborohydride and acetic acid in methanol at $-78{ }^{\circ} \mathrm{C}$ afforded a diastereomeric mixture corresponding to D-gluco- and L-ido-configurations 13a and 13b in the ratio 86:14, respectively. The separation of diastereoisomers at this stage, by flash chromatography, was troublesome due to the close $\mathrm{R}_{f}$ values. However, perbenzylation of the diastereomeric mixture $\mathbf{1 3}$ with benzyl bromide and sodium hydride in tetrahydrofuran afforded an easy access for chromatographic purification, and the required D-gluco-isomer 14a was obtained in good yield. One pot removal of diphenylmethyl and benzyl groups, in the D-gluco isomer 14a, by hydrogenolysis using ammonium formate, $10 \%$ palladium on activated carbon in methanol at $70{ }^{\circ} \mathrm{C}$ for 30 min gave 1,6-dideoxynojirimycin (9) as a colorless resin. The ${ }^{1} \mathrm{H}$ - and ${ }^{13} \mathrm{C}-\mathrm{NMR}$ data and specific rotation of $\mathbf{9}$ are known and were found to be parallel with those reported. ${ }^{9}$

The observed diastereoselectivity in the double reductive amination of $\mathbf{1 2}$ could be explained as follows. It is evident that sodium cyanoborohydride reductive amination of cyclic iminium ion intermediate is hydroxyl directed in which the $-\mathrm{OH}$ group at $\mathrm{C}-4$ plays a significant stereodirecting effect. The substituent at $\mathrm{C}-3$ is far away from the reactive site and therefore presumably has a lesser role in determining the stereochemistry of hydride addition. 


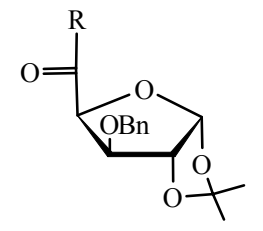

(i)

(ii)
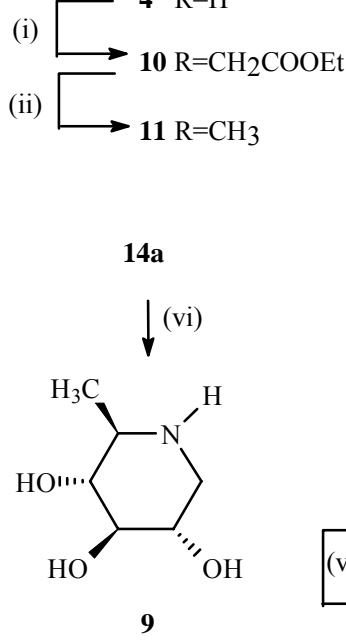

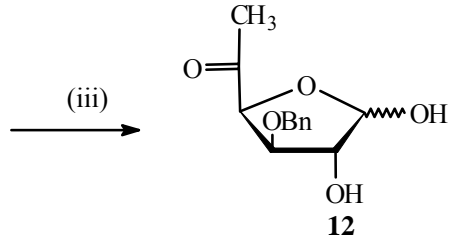

(iv)

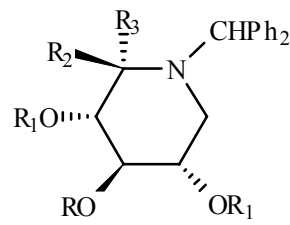

$\left\{\right.$ 13a, $\mathrm{R}=\mathrm{Bn}, \mathrm{R}_{1}=\mathrm{H}, \mathrm{R}_{2}=\mathrm{CH}_{3}, \mathrm{R}_{3}=\mathrm{H}$

(v) $13 \mathbf{b}, \mathrm{R}=\mathrm{Bn}, \mathrm{R}_{1}=\mathrm{H}, \mathrm{R}_{2}=\mathrm{H}, \mathrm{R}_{3}=\mathrm{CH}_{3}$ 14a, $\mathrm{R}=\mathrm{R}_{1}=\mathrm{Bn}, \mathrm{R}_{2}=\mathrm{CH}_{3}, \mathrm{R}_{3}=\mathrm{H}$ 14b, $\mathrm{R}=\mathrm{R}_{1}=\mathrm{Bn}, \mathrm{R}_{2}=\mathrm{H}, \mathrm{R}_{3}=\mathrm{CH}_{3}$

Scheme 2. Reagents and Conditions: (i) $\mathrm{N}_{2}=\mathrm{CHCOOEt}, \mathrm{BF}_{3}(\mathrm{EtO})_{2}, \mathrm{CH}_{2} \mathrm{Cl}_{2}, 0-2{ }^{\circ} \mathrm{C}$, 3h; (ii) DMSO, $\mathrm{H}_{2} \mathrm{O}, \mathrm{NaCl}, 135^{\circ} \mathrm{C}, 2 \mathrm{~h}$; (iii) $3 \mathrm{~N} \mathrm{HCl}$, THF, $70^{\circ} \mathrm{C}$, $2 \mathrm{~h}$; (iv) $\mathrm{H}_{2} \mathrm{NCHPh}_{2}, \mathrm{NaCNBH}_{3}$, $\mathrm{AcOH}, \mathrm{MeOH}-78^{\circ} \mathrm{C}$ to $20^{\circ} \mathrm{C}, 22 \mathrm{~h}$; (v) Nah, $\mathrm{BnBr}, n B u{ }_{4} \mathrm{NI}, 0$ to $20^{\circ} \mathrm{C}, 5 \mathrm{~h}$; (vi) $\mathrm{HCOONH}_{4}$, $10 \% \mathrm{Pd} / \mathrm{C}, \mathrm{MeOH}, 70^{\circ} \mathrm{C}, 30 \mathrm{~min}$

Now, we feel that the complexation of the reagent with $\alpha$-oriented C-4 hydroxy group favors the hydride attack from the $\alpha$-face (axial orientation), leading to the formation of D-glucoisomer as a major product (Figure 3).

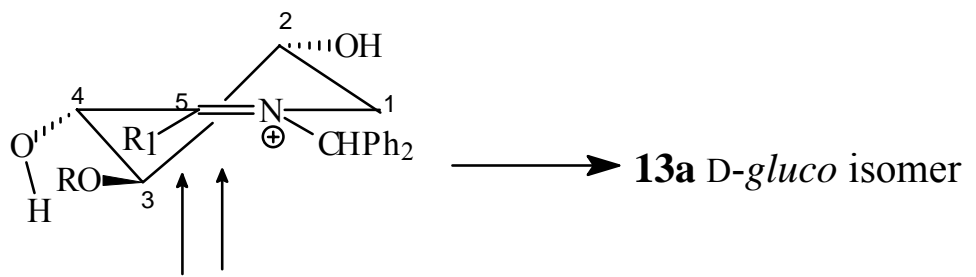

$$
\mathrm{R}=\mathrm{Bn}, \mathrm{R}_{1}=\mathrm{CH}_{3}
$$

Figure 3 


\section{Synthesis of 1-deoxy-L-ido-homo-nojirimycin (15) and 1-deoxy-D-gluco-homo-nojirimycin} (16)

In recent years, preparation and evaluation of homoazasugars with a $-\mathrm{CH}_{2}$ homologation either at C- 1 or at C-5 side chain as well as nojirimycin analogues with D- and/or L-configuration at C-5 have received much attention. In this connection, we are the first to report two independent pathways for the synthesis of $\mathbf{1 5}$ and 16. The first pathway involves intramolecular Michael addition of in situ generated $N$-benzylamine to D-glucose derived $\alpha, \beta$-unsaturated ester. ${ }^{10}$ Thus, Wittig reaction of 4 with (carbethoxymethylene) triphenylphosphorane gave an isomeric mixture of $\alpha, \beta$-unsaturated ester $17(E / Z=73: 27)$ that was separated by chromatography to afford 17a (Eisomer) and $17 \mathbf{b}$ ( $Z$-isomer) in $64 \%$ and $24 \%$ yield, respectively (Scheme 3 ). The cleavage of acetonide functionality in the geometrical mixture of $\mathbf{1 7}$ afforded hemiacetal 18 (anomeric mixture $\alpha: \beta=7: 3$ ) with an exclusive $E$-geometry at the double bond as indicated by the NMR spectra. One pot reaction of $\mathbf{1 8}$ with $N$-benzylamine (1.0 equiv.) in the presence of catalytic amounts of acetic acid in methanol followed by treatment with sodium cyanoborohydride afforded lactone 19a as the only isolable product. Thus, the overall three-step transformation presumably involves amine as the primary reaction product (by reductive amination at C-1), which undergoes concomitant Michael addition and domino lactonization to yield diastereoselective formation of 19a in 79\% yield. The lactone 19a was acetylated with acetic anhydride in pyridine to give 20a (78\%). The spectroscopic and analytical data obtained for 19a and 20a were in full accord with the assigned structures. The configuration at C-5 and the ${ }^{1} C_{4}$ conformation of 19a and 20a were determined from their high field ${ }^{1} \mathrm{H}$ NMR spectra based on the coupling constant values. In the subsequent steps, lactone 20a was reduced with lithium aluminum hydride in ether, and the primary alcohol 21a (colorless solid, 84\%) thus obtained was peracetylated to afford 21b (80\%). In the ${ }^{1} \mathrm{H}$ NMR spectra of 21a and 21b, H-3 showed a double doublet with large coupling constants $\left(J_{2,3}\right.$ and $\left.J_{3,4} \sim 8.8 \mathrm{~Hz}\right)$. This indicated the axial-axial relationship of $\mathrm{H}-3$ with $\mathrm{H}-2$ and

$\mathrm{H}-4$, confirming the change in conformation of the piperidine ring from ${ }^{1} C_{4}$ to ${ }^{4} C_{1}$. Finally, removal of the benzyl groups in 21a was achieved in one step using ammonium formate and 10\% palladium on activated carbon in methanol to give 1-deoxy-L-ido-homo-nojirimycin 15 (90\%). The ${ }^{1} \mathrm{H}$ - and ${ }^{13} \mathrm{C}-\mathrm{nmr}$ spectra and analytical data were in good agreement with the proposed structure with the ${ }^{4} C_{1}$ conformation.

The diastereoselective formation of 19a can be explained by considering the transition states $\mathbf{A}$ and $\mathbf{B}$ (Figure 4). In general, the stereo-electronic and steric factors often play an integral role in affecting the stereochemical outcome of the intramolecular Michael addition reactions. However, we believe that under the reaction conditions of borohydride reductive amination and in situ Michael addition, the complexation of boron with nitrogen and the C-2 and C-4 hydroxyl groups determine the amine additions. Thus, the complexation of the boron with $\mathrm{C}-2$ and $\mathrm{C}-4$ hydroxyl groups and the amine functionality holds the nitrogen atom in such a way that the preferred Si face attack at the diastereotopic $\beta$-carbon atom, as shown in transition state $\mathbf{A}$, leads to the formation of 19a. However, transition state $\mathbf{B}$ in which $R e$ face attack leads to the 
formation of the other isomer, is destabilized due to the non-bonded interactions of the $\alpha$-olefinic hydrogen with the $\mathrm{C}-1$ axial hydrogen and 3-O-benzyl group, explains why D-gluco isomer is not obtained.
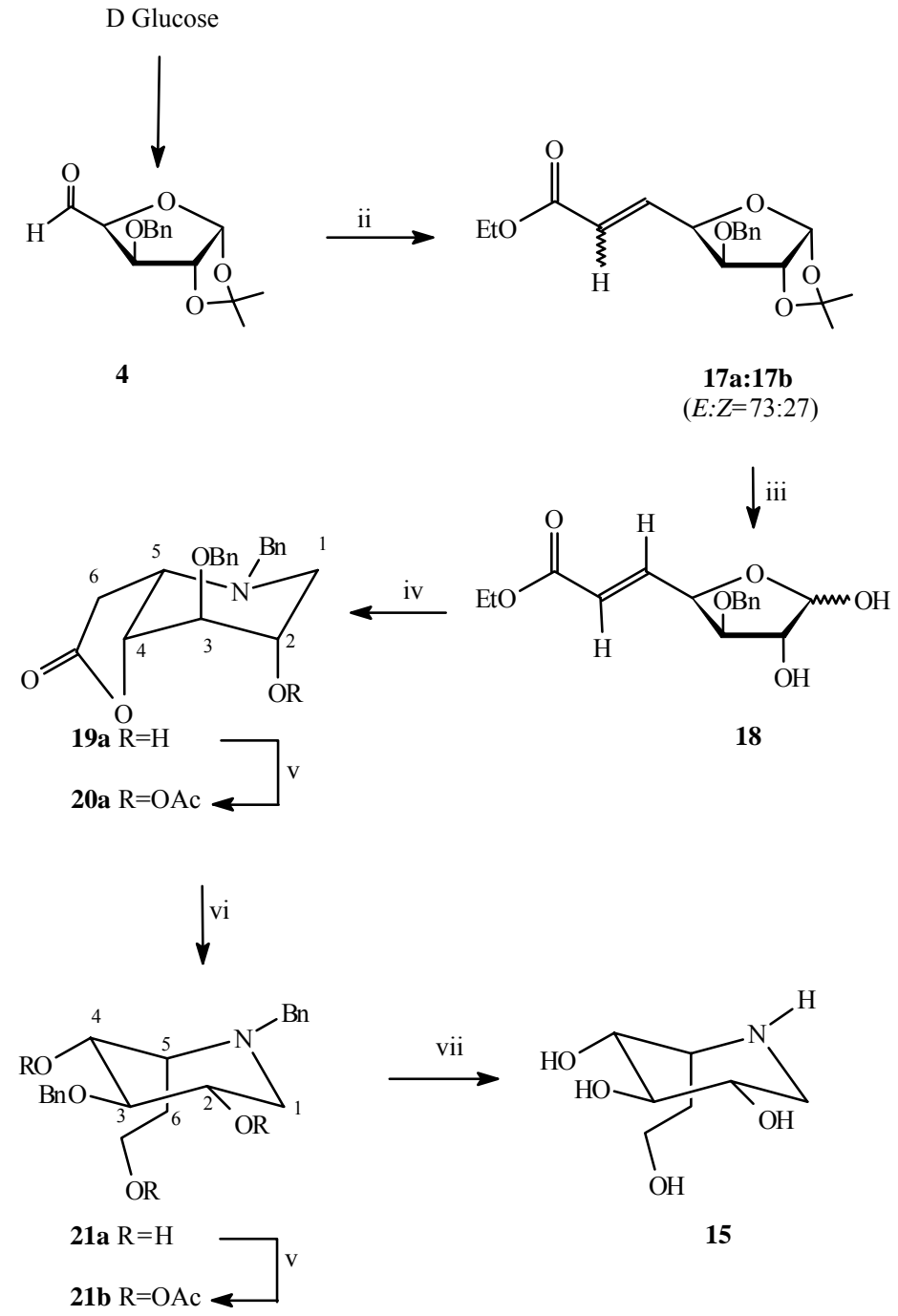

Scheme 3. Reagents and Conditions: (ii) $\mathrm{PPh}_{3} \mathrm{CHCOOEt}, \mathrm{MeCN}$, reflux, 2h; (iii) TFA-H2O (3:2), rt, 2h; (iv) $\mathrm{BnNH}_{2}, \mathrm{NaCNBH}_{3}, \mathrm{AcOH}, \mathrm{MeOH},-78^{\circ} \mathrm{C}, 2 \mathrm{~h}, 30^{\circ} \mathrm{C}, 24 \mathrm{~h}$; (v) $\mathrm{Ac}_{2} \mathrm{O}$, Pyridine, DMAP, $30{ }^{\circ} \mathrm{C}, 24 \mathrm{~h}$; (vi) LAH, THF, $0{ }^{\circ} \mathrm{C}$ to rt, $2 \mathrm{~h}$; (vii) $10 \% \mathrm{Pd} / \mathrm{C}, \mathrm{HCOONH}_{4}, \mathrm{MeOH}$, reflux, 1h. 


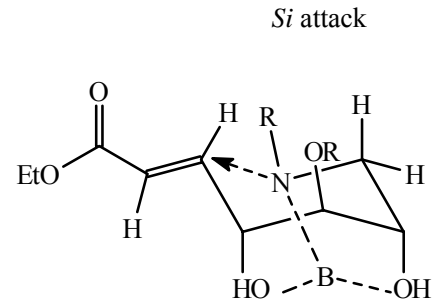

A

$$
\downarrow
$$

19a L-ido

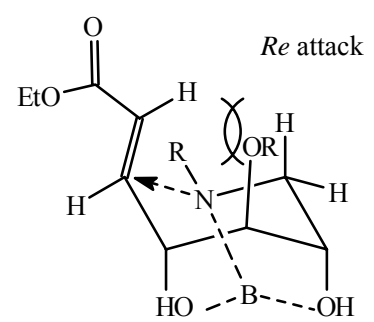

B

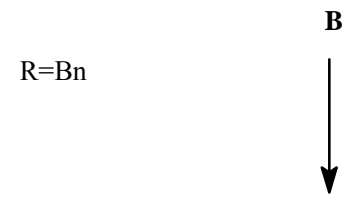

D-gluco

\section{Figure 4}

The second pathway towards the synthesis of homoazasugars $\mathbf{1 5}$ and $\mathbf{1 6}$ involves stereo controlled 1,3-addition reaction of silyl ketene acetal to D-glucose derived nitrone $\mathbf{5}$ as a key step $^{11}$. The 1,3-addition reaction of silyl ketene acetal 22 to D-glucose derived nitrone $\mathbf{5}$ in dichloromethane at $25^{\circ} \mathrm{C}$ for $24 \mathrm{~h}$ afforded an inseparable diastereomeric mixture of $O$-silyloxy$\beta$-amino esters 23a and 23b (Scheme 4). Determination of diastereomeric ratio, at the newly generated C5 stereocentre, was difficult at this stage. Therefore, the crude mixture of $O$-silyloxy$\beta$-amino esters 23 was subjected to $\mathrm{N}-\mathrm{O}$ bond reductive cleavage by treatment with zinc/copper couple in acetic acid-water at $70{ }^{\circ} \mathrm{C}$ for $1 \mathrm{~h}$ and the diastereomeric mixture of $N$-benzyl $\beta$-amino esters 24a and 24b was separated by flash chromatography (D-gluco: L-ido $=36: 64$ ) in good yield. Although, $\beta$-amino esters 24a and 24b were isolated in the pure form, their ${ }^{1} \mathrm{H}$ NMR data could not clearly discriminate the D-gluco and L-ido isomers. As a result, the assignment of configuration at $\mathrm{C} 5$ was made in the next stage. Thus, the reduction of the ester functionality in the $\beta$-amino esters $\mathbf{2 4 a}$ and $\mathbf{2 4 b}$, individually, with lithium aluminum hydride in tetrahydrofuran afforded $\beta$-amino alcohols $25 \mathbf{a}$ and $\mathbf{2 5 b}$, respectively. The assignment of configuration at $\mathrm{C} 5$ was made on the basis of the comparison of the ${ }^{1} \mathrm{H}$ NMR spectra and the diastereomeric ratio was found to be D-gluco:L-ido $=36: 64$.

Attempts were made to improve the diasteoselectivity of the 1,3 addition reaction by changing the reaction conditions and Lewis acids. As shown in Table 1, performing the reaction using acetonitrile as a solvent at different reaction conditions $\left(0^{\circ} \mathrm{C}\right.$ to reflux temperature $)$ led to a moderate change of stereoselectivity in favor of L-ido isomer (Table 1 entry 2, 3). In order to increase or alter the diastereoselectivity, we have investigated the influence of various Lewis acids. In this respect, the effect of trimethylsilyl triflate was first examined. The individual reactions of 22 with 5 were performed in the presence of 0.1 or 1.2 equiv. of trimethylsilyl 
triflate using either dichloromethane or acetonitrile as the solvent (Table 1, entry 4-7). Excellent yield with good diastereoselectivity (D-gluco: L-ido= 23:77), in favor of L-ido isomer, was achieved by using 1.2 equivalent of trimethylsilyl triflate in a binary mixture of dichloromethane and acetonitrile at $-78{ }^{\circ} \mathrm{C}$ (entry 5). We presumed that this trimethylsilyl triflate promoted reaction proceeds with the formation of $O$-silyloxy intermediate leading to the product formation in a non-chelation controlled manner.

The sugar nitrone 5 possesses two alkoxy substituents namely the furanose ring oxygen at the $\alpha$-position and benzyloxy group (at $\mathrm{C} 3$ ) at the $\beta$-position with respect to $\mathrm{C}=\mathrm{N}$ bond. These alkoxy substituents are considered to be promising chelating groups prone to enhance or alter the stereoselectivity of the reactions. This promoted us to make use of metal chelating Lewis acids such as zinc chloride/zinc iodide and magnesium bromide in the subsequent reactions. The use of either zinc chloride or zinc iodide under various conditions of temperature, solvent and mole proportions did not alter the diastereoselectivity (preponderance of L-ido isomer 23b) and stereoselectivity was also poor (Table 1, entry 8-15). Surprisingly, the replacement of zinc chloride with magnesium bromide altered the stereochemical course of the addition reaction (Table 1, entries 16-19). The best result was obtained by the use of 2.5 equiv. of magnesium bromide in a binary mixture of dichloromethane and acetonitrile at $-10{ }^{\circ} \mathrm{C}$ which afforded 23a (D-gluco-isomer) as the major product (23a:23b $=76: 24)$, in 94\% yield (entry 18). No significant effect was observed when the reaction was performed in acetonitrile as the solvent (entry 19).

The C5 amino alcohols 25a and 25b, with respective D-gluco- and L-ido- configurations, are the true intermediates for the synthesis of higher homologues of 1-deoxy-homo-nojirimycin. Thus, in subsequent steps, the one pot deprotection of $N$ - and O-benzyl groups in 25a, by treatment with $10 \%$ palladium on activated carbon in the presence of ammonium formate as a hydrogen donor in methanol, afforded amino alcohol 26a in 91\% yield. The C5-amino functionality in 26a was selectively protected with $\mathrm{Cbz}$ group using benzyl chloroformate in the presence of sodium bicarbonate in ethanol-water to obtain $\mathrm{N}$-Cbz protected amino alcohol 27a in $95 \%$ yield. Hydrolysis of 27a with trifluoroacetic acid-water at $0{ }^{\circ} \mathrm{C}$ to $25^{\circ} \mathrm{C}$ for $2 \mathrm{~h}$ afforded a hemiacetal which was directly subjected to hydrogenation using $10 \%$ palladium-carbon wherein deprotection of the $\mathrm{N}-\mathrm{Cbz}$ group, intramolecular amine cyclization, imine formation and reduction of the imino group, in one pot, gave 1-deoxy-D-gluco-homonojirimycin $\mathbf{1 6}$ as a pale yellow solid. In the ${ }^{1} \mathrm{H}$ NMR spectra, appearance of two triplets with large coupling constants one at $\delta 3.08$ corresponding to H-4 $\left(J_{4,5}=J_{3,4}=9.5 \mathrm{~Hz}\right)$ and other at $\delta 3.27$ for H-3 $\left(J_{2,3}=J_{3,4}=\right.$ $9.5 \mathrm{~Hz}$ ) indicated a trans diaxial relation with the adjacent protons. In the amino alcohol 25a, the relative stereochemistry of the substituents at $\mathrm{C} 2, \mathrm{C} 3$, and $\mathrm{C} 3, \mathrm{C} 4$ is trans and the same stereochemistry is retained in the product formation. The appearance of eight line pattern (ddd) at $2.51 \delta$ corresponding to H-5 with $J_{4,5}=9.5 \mathrm{~Hz}, J_{5,6}=8.8 \mathrm{~Hz}$, and $J_{5,6}=3.3 \mathrm{~Hz}$, confirmed the trans diaxial relative disposition of $\mathrm{H}-4$ and $\mathrm{H}-5$ protons. This confirms that the $\mathrm{C} 5$ substituent ($\left.\mathrm{CH}_{2} \mathrm{CH}_{2} \mathrm{OH}\right)$ is oriented equatorially [(5R)-configuration] and the compound $\mathbf{1 6}$ has the ${ }^{4} C_{1}$ conformation. 

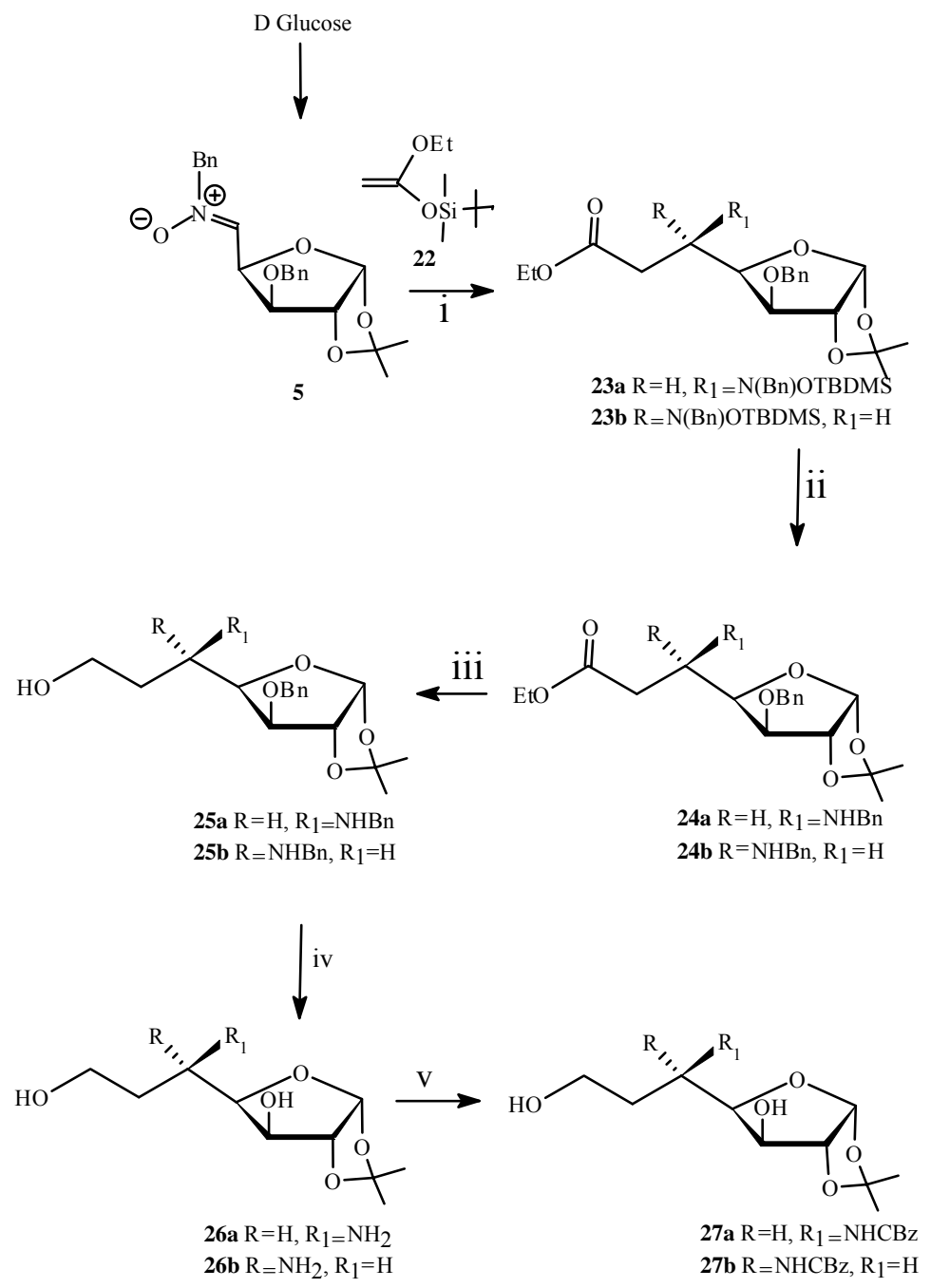

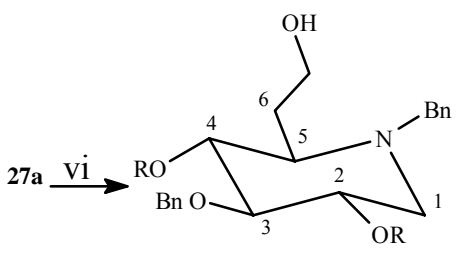

16

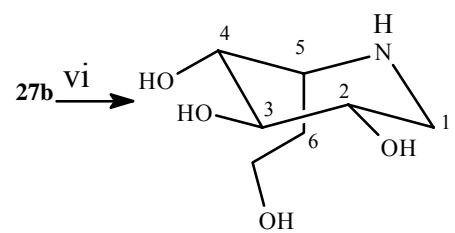

15

Scheme 4. Reagents and conditions; (i) Silyl ketene acetal, Lewis acid, $\mathrm{CH}_{2} \mathrm{Cl}_{2},-78^{\circ} \mathrm{C}$ or $-10^{\circ} \mathrm{C}, 1-24 \mathrm{~h}$; (ii) $\mathrm{Zn}-\mathrm{AcOH}, 70{ }^{\circ} \mathrm{C}, 2 \mathrm{~h}$; (iii) $\mathrm{LAH}, \mathrm{THF}, 0^{\circ} \mathrm{C}$ to $25^{\circ} \mathrm{C}, 2 \mathrm{~h}$; (iv) $\mathrm{HCOONH}_{4}, 10 \%$ $\mathrm{Pd} / \mathrm{C}, \mathrm{MeOH}, 12 \mathrm{~h}$; (v) $\mathrm{CBzCl}, \mathrm{NaHCO}_{3}, \mathrm{EtOH}-\mathrm{H}_{2} \mathrm{O}, 25^{\circ} \mathrm{C}, 2 \mathrm{~h}$; (vi) TFA- $\mathrm{H}_{2} \mathrm{O}{ }^{\circ} \mathrm{C}$ to $25^{\circ} \mathrm{C}, 2 \mathrm{~h}$ 
Table 1. Lewis acid catalysed addition of silyl ketene acetal 6 to nitrone 7

\begin{tabular}{|c|c|c|c|c|c|c|}
\hline \multirow[t]{2}{*}{ Run } & \multirow{2}{*}{$\begin{array}{l}\text { Lewis } \\
\text { acid } \\
\text { (equiv) }\end{array}$} & \multirow[t]{2}{*}{ Solvent $^{b}$} & \multicolumn{2}{|c|}{$\begin{array}{l}\text { Conditions } \\
\text { Temp. time }\end{array}$} & \multirow[t]{2}{*}{$\begin{array}{l}\text { Yield }^{\mathrm{a}} \\
(\%)\end{array}$} & \multirow[t]{2}{*}{$8 \mathrm{a}: 8 \mathrm{~b}$} \\
\hline & & & & $\mathrm{h}$ & & \\
\hline 1 & - & $\mathrm{CH}_{2} \mathrm{Cl}_{2}$ & 25 & 24 & 95 & $36: 64$ \\
\hline 2 & - & $\mathrm{CH}_{3} \mathrm{CN}$ & 25 & 20 & 95 & $34: 66$ \\
\hline 3 & - & $\mathrm{CH}_{3} \mathrm{CN}$ & 80 & 4 & 80 & $30: 70$ \\
\hline 4 & $\begin{array}{l}\text { TMSOTf } \\
(1.2)\end{array}$ & $\mathrm{CH}_{2} \mathrm{Cl}_{2}$ & -78 & 1.5 & 94 & $34: 66$ \\
\hline 5 & $\begin{array}{l}\text { TMSOTf } \\
(1.2)\end{array}$ & $\begin{array}{c}\mathrm{CH}_{2} \mathrm{Cl}_{2} \\
+ \\
\mathrm{CH}_{3} \mathrm{CN}\end{array}$ & -78 & 1.5 & 93 & 23:77 \\
\hline 6 & $\begin{array}{l}\text { TMSOTf } \\
(0.1)\end{array}$ & $\begin{array}{c}\mathrm{CH}_{2} \mathrm{Cl}_{2} \\
+ \\
\mathrm{CH}_{3} \mathrm{CN}\end{array}$ & -78 & 15 & 96 & $31: 69$ \\
\hline 7 & $\begin{array}{l}\text { TMSOTf } \\
(0.1)\end{array}$ & $\mathrm{CH}_{3} \mathrm{CN}$ & 25 & 2.0 & 93 & $25: 75$ \\
\hline 8 & $\begin{array}{l}\mathrm{ZnCl}_{2} \\
(1.2)\end{array}$ & $\mathrm{CH}_{2} \mathrm{Cl}_{2}$ & -78 & 24 & No reac & tion \\
\hline 9 & $\begin{array}{l}\mathrm{ZnCl}_{2} \\
(1.2)\end{array}$ & $\mathrm{CH}_{2} \mathrm{Cl}_{2}$ & -40 & 2.0 & 94 & $40: 60$ \\
\hline 10 & $\begin{array}{l}\mathrm{ZnCl}_{2} \\
(1.2)\end{array}$ & $\begin{array}{c}\mathrm{CH}_{2} \mathrm{Cl}_{2} \\
+ \\
\mathrm{CH}_{3} \mathrm{CN}\end{array}$ & -40 & 2.0 & 96 & $42: 58$ \\
\hline 11 & $\begin{array}{l}\mathrm{ZnCl}_{2} \\
(3.0)\end{array}$ & $\begin{array}{c}\mathrm{CH}_{2} \mathrm{Cl}_{2} \\
+ \\
+ \\
\mathrm{CH}_{3} \mathrm{CN}\end{array}$ & -40 & 2.0 & 85 & $45: 55$ \\
\hline 12 & $\begin{array}{l}\mathrm{ZnI}_{2} \\
(1.2)\end{array}$ & $\mathrm{CH}_{2} \mathrm{Cl}_{2}$ & -78 & 24 & No rea & tion \\
\hline 13 & $\begin{array}{l}\mathrm{ZnI}_{2} \\
(1.2)\end{array}$ & $\mathrm{CH}_{2} \mathrm{Cl}_{2}$ & -40 & 2.0 & 92 & $50: 50$ \\
\hline 14 & $\begin{array}{l}\mathrm{ZnI}_{2} \\
(1.2)\end{array}$ & $\begin{array}{c}\mathrm{CH}_{2} \mathrm{Cl}_{2} \\
+ \\
\mathrm{CH}_{3} \mathrm{CN}\end{array}$ & -40 & 2.0 & 91 & $46: 54$ \\
\hline 15 & $\begin{array}{l}\mathrm{ZnI}_{2} \\
(3.0)\end{array}$ & $\begin{array}{c}\mathrm{CH}_{2} \mathrm{Cl}_{2} \\
+ \\
\mathrm{CH}_{3} \mathrm{CN}\end{array}$ & -40 & 2.0 & 83 & $46: 54$ \\
\hline 16 & $\begin{array}{l}\mathrm{MgBr}_{2} \\
(1.2)\end{array}$ & $\mathrm{CH}_{2} \mathrm{Cl}_{2}$ & -78 & 24 & No reac & tion \\
\hline 17 & $\begin{array}{l}\mathrm{MgBr}_{2} \\
(1.2)\end{array}$ & $\mathrm{CH}_{2} \mathrm{Cl}_{2}$ & -10 & 2.0 & 90 & $60: 40$ \\
\hline 18 & $\begin{array}{l}\mathrm{MgBr}_{2} \\
(2.5)\end{array}$ & $\begin{array}{c}\mathrm{CH}_{2} \mathrm{Cl}_{2} \\
+ \\
\mathrm{CH}_{3} \mathrm{CN}\end{array}$ & -10 & 2.0 & 94 & $76: 24$ \\
\hline 19 & $\begin{array}{l}\mathrm{MgBr}_{2} \\
(2.5) \\
\end{array}$ & $\mathrm{CH}_{3} \mathrm{CN}$ & -10 & 2.0 & 90 & $74: 26$ \\
\hline
\end{tabular}

${ }^{a}$ Yields refer to the isolated yields after column chromatography.

${ }^{b} \mathrm{CH}_{2} \mathrm{Cl}_{2}+\mathrm{CH}_{3} \mathrm{CN}$ in the ratio 1:1. 
In an analogous reaction sequence, the pure $N$-benzyl amino alcohol $25 \mathbf{b}$ on hydrogenolysis gave 26b, which on selective $N$-protection afforded $N$-Cbz-amino alcohol 27b. In the next step, removal of the acetonide group followed by the hydrogenation afforded 1-deoxy L-ido-homonojirimycin 15 in $78 \%$ yield from 25 . Since the ${ }^{1} \mathrm{H}$ NMR spectrum of $\mathbf{1 5}$ is very different from 16, it was thought that 15 could exist in the ${ }^{1} C_{4}$ conformation. However, appearances of two distinct doublets of doublets for H-1a at $\delta 2.62\left(J_{1 \mathrm{a}, 1 \mathrm{e}}=13.3 \mathrm{~Hz} ; J 1 \mathrm{a}, 2=8.2 \mathrm{~Hz}\right)$ and for $\mathrm{H}-1 \mathrm{e}$ at $\delta 2.88\left(J_{1 \mathrm{a}, 1 \mathrm{e}}=13.3 \mathrm{~Hz} ; J_{1 \mathrm{e}}, 2=4.2 \mathrm{~Hz}\right)$ were informative. The large coupling constant $\left(J_{1 \mathrm{a}, 2}=\right.$ $8.2 \mathrm{~Hz}$ ) for the $\mathrm{H}-1$ axial proton requires trans diaxial relationship with $\mathrm{H}-2$ proton. This clearly requires H-2 proton to be axial and suggestive of the fact that compound 15 exits in ${ }^{4} C_{1}$ conformation. The ${ }^{1} \mathrm{H}$ and ${ }^{13} \mathrm{C}$ NMR spectral and analytical data was also found to be in consonance with the data reported earlier by us thus conforming the ${ }^{4} C_{1}$ conformation with (5S)configuration.

\section{Explanation for the observed diastereoselectivity}

According to the Felkin-Anh model two conformations $\mathbf{C}$ and D (Figure 5) were considered for the trimethyl silyl triflate assisted nitrone addition reaction. Although, transition state $\mathbf{C}$ is preferred over $\mathbf{D}$, the attack of the bulky silyl ketene acetal, along the Burgi-Dunitz trajectory from the $R e$ face is disfavored by the C3-benzyloxy substituent. This explains why D-gluco isomer 23a is obtained as a minor product. However, in the alternate transition state $\mathbf{D}$, the attack of the silyl ketene acetal from the opposite face of the bulky C3-benzyloxy group (Si face) is strongly favored due to the minimized steric non-bonded interactions, leading to the preferential formation of the L-ido-isomer $\mathbf{2 3 \mathbf { b }}$ as a major product.

The stereochemical outcome in the bivalent metal assisted reaction could be explained by considering the chelated transition states involving the metal complexation with nitrone oxygen and proximate alkoxy groups. Two conformations $\mathbf{E}$ and $\mathbf{F}$ were therefore considered. The $\alpha-$ chelation of the nitrone oxygen with furanose ring oxygen, in a six membered transition state, is represented in $\mathbf{E}$ while the $\beta$-chelation with the $\mathrm{C} 3$-benzyloxy substituent resembles the model $\mathbf{F}$. For the reaction in the presence of magnesium bromide, we assume that the reactive transition state that resemble the complexation of magnesium hydroxyl amine with the C3-benzyloxy group prevails ( $\beta$-chelated model $\mathbf{F}$ ) wherein; Re facial nucleophilic addition, from the small group, gives the observed D-gluco stereoselectivity (anti product). In case of zinc chloride or zinc iodide mediated addition reactions with nitrone, with $\alpha$ and $\beta$-alkoxy substituents in the proximity, earlier worker have shown that the $\alpha$-chelation model explains the observed stereoselectivity. Thus, nucleophilic attack from the preferred Si face in conformer $\mathbf{E}$ affords the syn-adduct albeit in poor selectivity. 


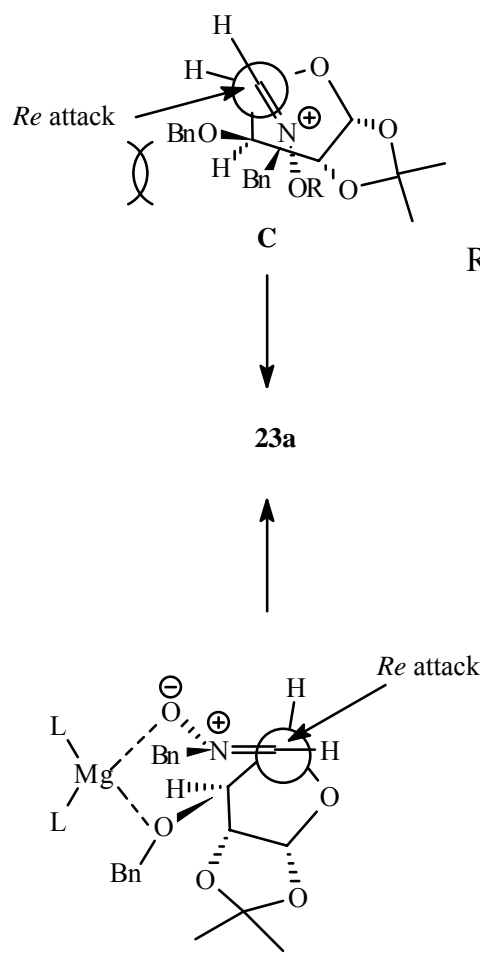

$\mathbf{F}$
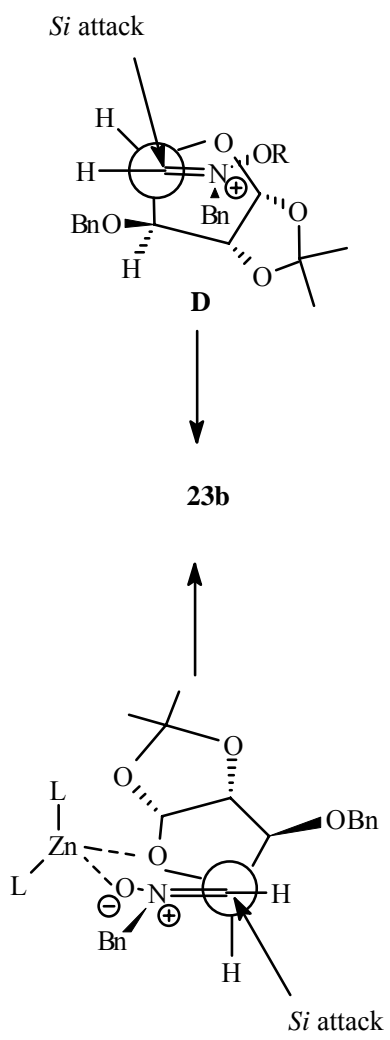

$\mathbf{E}$

\section{Figure 5}

In conclusion, we have demonstrated various pathways to the synthesis of polyhydroxylated piperidine analogues. The easy and cheap availability of starting material, mild reaction conditions and simple reagents with good diastereoselectivity make our routes attractive which can be worked out on multigram scale.

\section{Acknowledgements}

We are grateful to AICTE, New Delhi for financial support. VND, NNS and JNT are thankful to UGC and CSIR for fellowships.

\section{References}

1. (a) Wong, C.-H.; Halcomb, R. L.; Ichikawa,Y.; Kajimoto,T. Angew. Chem., Int. Ed. 1995, 34, 412. (b) Wong, C.-H.; Halcomb, R. L.; Ichikawa,Y.; Kajimoto,T. Angew. Chem., Int. Ed. 1995, 34, 521. (c) Sinnott, M. L. Chem. Rev. 1990, 90, 1171. (d) Fleet, G. W. J.; Namgoong, S. K.; Barker, C.; Baines, S.; Jacob, G. S.; Winchester, B.; Tetrahedron Lett. 1989, 30, 4439 
2. (a) Paulsen, H.; Todt, K. Adv. Carbohydr. Chem. 1968, 23, 115. (b) Fellows, L. E. Chem. Ber. 1987, 23, 842. (c) Truscheit, E.; Frommer, W. Junge, B.; Muller, L.; Schmith, D. D.; Wingender, W. Angew. Chem., Int. Ed. 1981, 20, 744. (d) Inouye, S.; Tsuruoka, T.; Ito, A.; Niida, T. Tetrahedron 1968, 24, 2125. (e) Muller, L. In Biotechnology; Rehn, H.-J.; Reed, G. Eds; VCH Verlagsgeselschaft: Weinheim, 1985; Vol. 4 Ch. 18. (f) Sinnott, M. L. Chem Rev. 1990, 90, 1171. (g) Winchester, B.; Fleet, G. W. J.; Glycobiology. 1992, 2, 199. (h) Wong, C.-H.; Halcomb, R. L.; Ichikawa,Y.; Kajimoto,T.; Angew. Chem., Int. Ed. 1995, 34, 412. (i) Wong, C.-H.; Halcomb, R. L.; Ichikawa,Y.; Kajimoto, T. Angew. Chem., Int. Ed. 1995, 34, 521 and references cited therein

3. Kajimoto, T.; Liu, K. K.-C.; Pederson,R. L.; Zhong, Z.; Ichikawa,Y.; Porco J. A., Jr.; Wong, C.-H. J. Am. Chem. Soc. 1991, 113, 6187 and references cited therein.

4. (a) Fellows, L. E.; Fleet, G. W. J. Natural Product Isolation; Elsevier:Amsterdam, 1988; Ch. 13, p 539. (b)Winchester, B.; Fleet, G. W. J.; Glycobiology 1992, 2, 199. (c) Looks, G. C.; Fotsch, C. H.; Wong, C.-H. Acc. Chem. Res. 1993, 26, 182. (d) Waynaroska, B.; Wilkiel, H.; Sharma, M.; Carpenter, N.; Fleet, G. W. J.; Bernacki, R. J. Anticancer Res. 1992, 12, 161. (e) Karpas, A.; Fleet, G. W. J.; Dwek, R. A; Petursson, S.; Namgoong, S. K.; Ramsden, N. G.; Jacob, G. S.; Rademacher, T. W. Proc. Natl. Acad. Sci. U.S.A. 1998, 85, 9229. (f) Fleet, G. W. J.; Karpas, A.; Raymond A. D.; Fellows, L. E.; Tyms, A. S.; Petursson, S.; Namgoong, S. K.; Ramsden, N. G.; Smith, P. W.; Son, J. C.; Wilson, F.; Witty, D. R.; Jacob, G. S.; Rademacher, T. W. FEBS Lett. 1998, 237, 128. (g) Datema, R.; Olofsson, S.; Romero, P. A. Pharmacol. Ther. 1987, 33, 221. (h) Kino, N.; Inamura, N.; Nakahara, K.; Tsurumi, T.; Adachi, K.; Shibata, T.; Terano, H.; Kohsaka, M.; Aoki, H.; Imanaka, H. J. Antibiot. 1985, 38, 936.

5. (a) Truscheit, E.; Frommer, W. Junge, B.; Muller, L.; Schmith, D. D.; Wingender, W. Angew. Chem., Int. Ed. 1981, 20, 744. (b) Furneaux, R. H.; Gainsford, G. J.; Mason, J. M.; Tyler, P. C.; Hartley, O.; Wincheter, B. G. Tetrahedron 1997, 57, 245. (c) Humphires, M. J.; Matsumoto, K.; White, S. L.; Olden, K. Cancer Res. 1986, 46, 5215. (d) Karpas, A.; Fleet, G. W. J.; Dwek, R. A; Petursson, S.; Namgoong, S. K.; Ramsden, N. G.; Jacob, G. S.; Rademacher, T. W. Proc. Natl. Acad. Sci. U.S.A. 1998, 85, 9229. (e) Walker, B. D.; Kowalski, M.; Goh, W. C.; Kozarsky, K.; Krieger, M.; Rosen, C.; Rohrschneider, L.; Heseltine,W. A.; Sodroski, J. Proc. Natl. Acad. Sci. U.S.A. 1998, 84, 8120. (f) Sunkara, P.S.; Sjoerdsma, A. Biochem. Biophys. Res. Commun. 1987, 148, 206. (g) Bernotas, R. C.; Papendreou, G.; Urbach, J.; Ganem, B. Tetrahedron Lett. 1990, 31, 3393.

6. Dhavale, D. D.;Desai, V. N.; Sindkhedkar, M. D.; Mali, R. S.; Castellari, C.; Trombini, C. Tetrahedron: Asymmetry 1997, 8, 1475 and references cited therein

7. Defoin, A.; Sarazin, H.; Streith, J. Tetrahedron 1997, 53, 13783

8. Dhavale, D. D.; Saha, N. N.; Desai, V. N. J. Org. Chem. 1997, 62, 7482.

9. (a) Kajimoto,T.; Liu, K. K.-C.; Pederson,R. L.; Zhong, Z.; Ichikawa,Y.; Porco J. A., Jr.; Wong, C.-H.; J Am. Chem. Soc. 1991, 113, 6187. (b) Defoin, A.; Sarazin, H.; Streith, J. Helv. Chim. Acta 1996, 79, 560. 
10. Dhavale, D. D.; Desai, V. N.; Saha, N. N. Chem. Commun. 1999, 1719.

11. Dhavale, D. D.; Saha, N. N.; Desai, V. N. Tetrahedron 2001, 57, 39. 